\title{
The ovarian follicular wave pattern and induction of ovulation in the mated and non-mated one-humped camel (Camelus dromedarius)
}

\author{
J. A. Skidmore ${ }^{1,2}$, M. Billah ${ }^{1}$ and W. R. Allen ${ }^{2 *}$ \\ ${ }^{1}$ The Camel Reproduction Laboratory, Nakhlee, PO Box 11808, Dubai, UAE; and ${ }^{2} T B A$ Equine \\ Fertility Unit, Mertoun Paddocks, Woodditton Road, Newmarket, Suffolk CB8 9BH, UK
}

\begin{abstract}
Ovarian follicular wave patterns were studied ultrasonographically in three groups of dromedary. Group I camels $(n=20)$ were teased daily with a vasectomized male but mating was prevented; group 2 camels $(n=8)$ ran freely with a vasectomized male camel for $10 \mathrm{~h}$ each day and group 3 camels $(n=8)$ were kept completely separate from any males. In a second experiment $(n=63)$, when the diameter of the dominant follicle reached $0.5-0.9 \mathrm{~cm}$, $1.0-1.9 \mathrm{~cm}, 2.0-2.9 \mathrm{~cm}$ or $>3 \mathrm{~cm}$, the camel was given one of three treatments to induce ovulation: (i) natural mating; (ii) $20 \mu \mathrm{g}$ of the GnRH analogue, buserelin; or (iii) $3000 \mathrm{iu} \mathrm{hCG}$. The ovaries were re-scanned regularly to monitor ovulation, and daily blood samples were assayed for progesterone and oestradiol concentrations. The follicular cycle was divisible into a growth phase (10.5 \pm 0.5 days), a mature phase (7.6 \pm 0.8 days) and a regression phase ( $11.9 \pm 0.8$ days). The dominant follicle reached a mean \pm SEM maximum diameter of $2.0 \pm 0.1 \mathrm{~cm}$ (range $1.5-2.5 \mathrm{~cm}$ ) in 34 cycles $(52 \%)$ before it began to regress. In the other 32 cycles $(48 \%)$, however, the dominant follicle continued to grow to $4.2 \pm 0.2 \mathrm{~cm}$ (range $4.0-6.0 \mathrm{~cm}$ ) before regression commenced. Group 2 camels were mated when their follicles reached $1.3 \pm 0.1 \mathrm{~cm}$ in diameter and the mean interval between successive matings was $13.8 \pm 1.0$ days. Mean \pm SEM serum concentrations of oestradiol reached peak values at $39.0 \pm 1.8 \mathrm{pg} \mathrm{ml}^{-1}$, when the dominant follicle measured $1.7 \pm 0.1 \mathrm{~cm}$ and, after ovulation, mean serum concentrations of progesterone reached peak values at $2.6 \pm 0.3 \mathrm{ng} \mathrm{ml}{ }^{-1}$ on day 8 , before decreasing to $<1 \mathrm{ng} \mathrm{ml}^{-1}$ by day 10 or 11 . When the dominant follicle measured $0.5-0.9 \mathrm{~cm}$ in diameter, $70 \%, 60 \%$ and $60 \%$ of them ovulated in response to mating, or treatment with buserelin or hCG, respectively. These ovulation rates increased to $85 \%$ (mating), $81 \%$ (buserelin) and $67 \%$ (hCG) when the follicle measured $1-1.9 \mathrm{~cm}$, but they decreased again to $12.5 \%$ (mating), $29 \%$ (buserelin) and 13\% (hCG) when the diameter had increased to $2.0-2.9 \mathrm{~cm}$ at the time of treatment. No follicles measuring $>3.0 \mathrm{~cm}$ ovulated in response to any of the treatments. These results indicated that the optimum time to mate or attempt to induce ovulation in the female dromedary is when the growing follicle measures $0.9-1.9 \mathrm{~cm}$ in diameter.
\end{abstract}

\section{Introduction}

Camelids of the New World (e.g. llama and alpaca) and the Old World (dromedary and bactrian camel) are seasonal breeders and induced ovulators (Fernandez Baca et al., 1970; Musa and Abusineina, 1978; Adams et al., 1990; Bravo et al., 1990). Original studies on the follicular wave pattern in dromedaries were based on ovaries obtained from an abattoir and on serial palpations of the ovaries per rectum in small numbers of camels. From these surveys the duration of the follicular wave was reported to range from 17.2 to 23.4 days in India (Joshi et al., 1978), and to have a mean duration of 24.2 days in Egypt (Wilson, 1984) and 28 days in Sudan (Musa and Abusineina, 1978). In bactrian camels, Chen and Yuen (1979) reported a

*Correspondence.

Revised manuscript received 1 November 1995 mean follicular wave duration of 19 days, with a range of 14-21 days. More recently, realtime ultrasonography has been used to monitor day-to-day ovarian follicular changes in large animals such as cows (Savio et al., 1988; Sirois and Fortune, 1988), sheep (Ravindra et al., 1994), horses (Pierson and Ginther, 1987; Sirois et al, 1989) and llamas (Adams et al., 1990; Bravo et al., 1990). In cows, large antral follicles grow in two (Ginther et al., 1989) or three (Savio et al., 1988; Sirois and Fortune, 1988) waves, each of which is characterized by the simultaneous emergence of a cohort of follicles from a pool of small follicles and the establishment of a dominant follicle that continues to develop while apparently suppressing the growth of the other follicles (Fortune et al., 1988; Pierson and Ginther, 1988; Savio et al., 1988).

The factors that control ovulation in the camelids are not well understood. In bactrian camels, ovulation can be induced by deep intravaginal deposition of whole semen or sperm-free Downloaded from Bioscientifica.com at 04/26/2023 01:16:54PM via free access 
seminal plasma (Chen et al., 1985), as well as by i.m. injection of semen or seminal fluid (Zhao et al., 1990). In dromedaries, ovulation is induced by mating with an intact or vasectomized male (Marie and Anouassi, 1987), but manual stimulation of the cervix or intrauterine injection of whole semen, seminal plasma, water or the prostaglandin $\mathrm{F}$ analogue, cloprostenol, does not stimulate the release of sufficient LH from the pituitary to cause ovulation (Musa and Abusineina, 1978; Sheldrick et al., 1992). Efficient methods to induce and synchronize ovulation in dromedaries are now required as interest grows in the potential application of artificial insemination and embryo transfer to this species (Cooper et al,, 1992). However, mating to a vasectomized male is not acceptable because of the potential for spreading venereal diseases. This leaves treatment with an LH-like gonadotrophic hormone at the optimal time in the follicular growth cycle as the most practical alternative.

The purpose of the present study was twofold. First, to define accurately the patterns of follicular growth and regression in dromedaries by means of repeated realtime ultrasonographic examinations of the ovaries, and to relate these morphological events to changes in behaviour and steroid hormone concentrations in peripheral blood. Second, to compare the efficacy of two forms of gonadotrophin therapy to induce ovulation in non-mated camels and to determine the optimal time in the follicular wave cycle for their application.

\section{Materials and Methods}

\section{Animals}

A total of 73 mature female dromedaries aged 5-14 years was used in two experiments. They were maintained in groups of 8-30 animals in fenced pens, each of $0.002-0.004 \mathrm{~km}^{2}$ area. They were fed a diet of mixed concentrates and lucerne hay once a day and were given water ad libitum. Thirty-six camels were used in Expt 1 (1 December-31 January, 1993-1994) and 60 were used in Expt 2 (12 November-30 March, 1993-1994).

\section{Ovarian examinations}

The ovaries of every camel were examined on alternate days throughout the defined experimental periods by transrectal ultrasonography as described by Skidmore et al. (1992). An Aloka Model 500 realtime scanner with a $5 \mathrm{MHz}$ linear array transducer (Al Carmal Ltd, Dubai, UAE) was used and all follicles $\geq 0.5 \mathrm{~cm}$ in diameter and corpora lutea present in both ovaries were counted, measured using the internal electronic calipers and photographed using a Sony Model UP $860 \mathrm{CE}$ videoprinter (Al Carmal Ltd) interfaced with the scanner.

\section{Blood sampling and hormone assays}

Samples of jugular vein blood $(8 \mathrm{ml})$ were recovered daily from all camels throughout the experimental periods. They were kept at room temperature $\left(19-23^{\circ} \mathrm{C}\right)$ for $1-2 \mathrm{~h}$ before being centrifuged at $1500 \mathrm{~g}$ for $5 \mathrm{~min}$. The serum was decanted and stored at $-20^{\circ} \mathrm{C}$ until subsequent assay for progesterone and oestradiol. Owing to a limited supply of antibody and

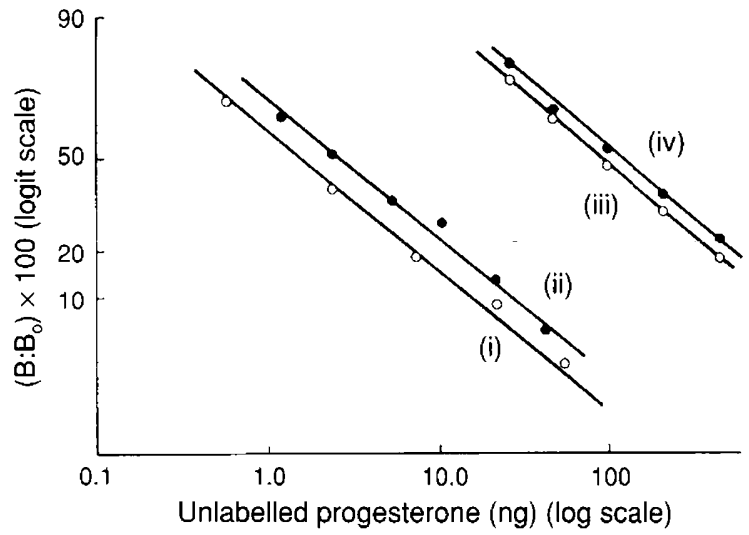

Fig. 1. Typical standard curves for the progesterone assay: (i) standards made up in human serum supplied in the assay kit; (ii) standards made up in charcoal-stripped male camel serum; (iii) and (iv) serial dilutions of a sample of camel serum containing a high concentration of progesterone diluted in either (iii) human serum or (iv) charcoal-stripped male camel serum. Results are plotted as $\log -\operatorname{logit}$ linear transformations.

other materials for the oestradiol assay, the sera from only eight camels could be assayed for oestradiol concentration. These animals were selected randomly from Group 1 of Expt 1 .

Progesterone assay. Progesterone concentrations were measured directly in $25 \mu \mathrm{l}$ aliquots of sample or standard in a commercially available assay kit (Amerlite Progesterone Assay: Kodak Clinical Diagnostics, Amersham) which used a competitive immunoassay technique based on enhanced luminescence (Whitehead $e t$ al., 1983). The suitability of the assay for use with camel serum was tested by comparing the parallelism of the standard curves produced by standards made up in charcoal-stripped male camel serum and the human serum provided in the assay kit. In addition, a sample of pregnant female camel serum with a high progesterone concentration was diluted serially in male camel serum and human serum and run against the standard curves in the assay. All the curves were parallel with the kit standard curve (Fig. 1), indicating that camel serum did not interfere with binding in the assay. The minimum detection limit of the assay was $0.11 \mathrm{ng}$ progesterone $\mathrm{ml}^{-1}$ serum and the intra- and interassay coefficients of variation, calculated by the method described by Dighe and Hunter (1976), were found to be $7.5 \%$ and $8 \%$, respectively. The crossreactivities of the anti-progesterone serum used in the assay were stated by the manufacturers to be $5.2 \%$ with $5 \alpha$-pregnane-3,20-dione, $4.17 \%$ with $5 \beta$-pregnane-3,20-dione and $1.1 \%$ with $20 \alpha$-dihydroprogesterone.

Oestradiol assay. Concentrations of free oestradiol were measured in selected sera recovered in Expt I, using a radioimmunoassay based on the method described by Heap and Hamon (1979). The anti-oestradiol serum was raised in a rabbit immunized with oestradiol-6-(CMO) conjugated to bovine serum albumin (E002; Steranti Research Ltd, Herts) and it showed stated crossreactivities of $0.55 \%$ with oestrone and $0.19 \%$ with oestriol. Aliquots ( $\mathrm{I} \mathrm{ml}$ ) of serum were extracted with $5 \mathrm{ml}$ diethyl ether before being assayed in duplicate. To measure procedural losses during the extraction process, $0.1 \mathrm{ml}$ Downloaded from Bioscientifica.com at 04/26/2023 01:16:54PM 


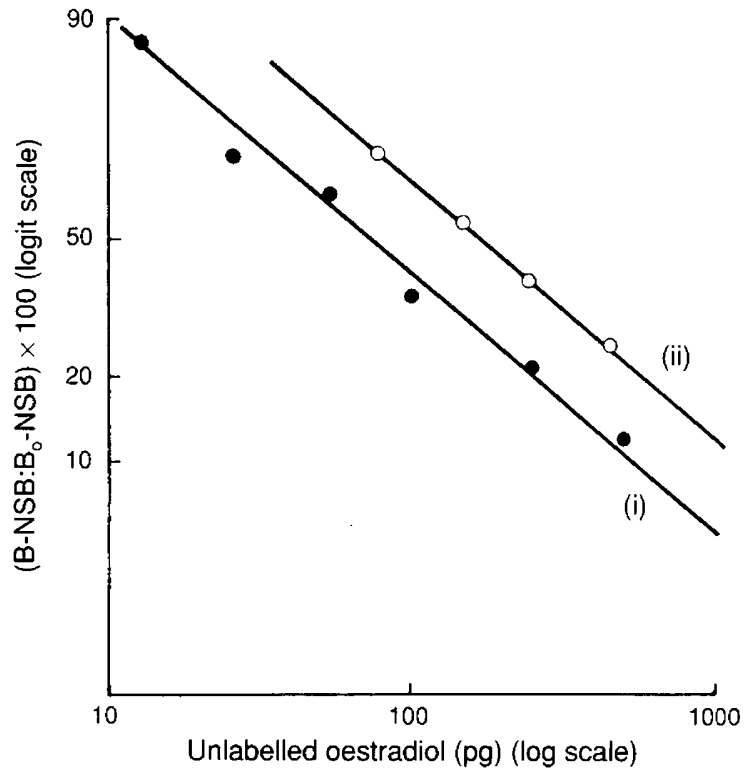

Fig. 2. (i) A typical standard curve for oestradiol and, (ii) a serial dilution curve of a sample of camel serum known to contain a high concentration of oestradiol. Results are plotted as log-logit linear transformations. NSB: nonspecific binding.

of the tritiated oestradiol $([2,4,6,7-\mathrm{H}]$ oestradiol; specific activity $3.15 \mathrm{TBq} \mu \mathrm{mol}^{-1}$; Amersham Life Sciences, Bucks) was added to $1 \mathrm{ml}$ of charcoal-stripped male camel serum and extracted as above. This gave a mean recovery rate of $82.0 \pm 1.7 \%$.

The assay was validated for camel serum by measuring the recovery of oestradiol added to a sample of male camel serum to give concentrations of 25,100 and $250 \mathrm{pg}$ oestradiol ml ${ }^{-1}$; the mean recovery of this cold oestradiol was $109 \pm 6.9 \%$. In addition, a sample of camel serum containing a known high concentration of oestradiol was diluted serially and assayed against the standard curve. This gave a parallel curve, thereby indicating that camel serum did not interfere with binding in the assay (Fig. 2). The intra- and interassay coefficients of variation were $6.2 \%$ and $10.1 \%$, respectively, and the mean minimum detection limit was $8.3 \mathrm{pg} \mathrm{ml}^{-1}$.

\section{Experimental design}

Experiment 1. The 36 camels in this experiment were divided into three groups. Group 1 animals $(n=20)$ were kept in one pen and were teased daily with a vasectomized male camel for at least $30 \mathrm{~min}$ in the early morning. Signs of oestrus (following the male, stradling the hind legs, lifting the tail and urinating when being examined by the male) were recorded but mating was not allowed. Group $2(n=8)$ camels were kept in another pen in which a vasectomized male was allowed to run freely for $10 \mathrm{~h}$ each day. They were observed constantly for signs of oestrus and any matings that occurred were recorded and timed. Group $3(n=8)$ camels were kept together in an isolated pen that was out of the sight, sound and smell of any male camels so that their follicular wave patterns could be monitored in the complete absence of any male influence.

On the basis of the alternate day scanning results, a growth and regression profile of the dominant follicle was plotted for each camel in the three groups. This was defined as a follicle that grew to at least $1.5 \mathrm{~cm}$ and exceeded the diameter of all other follicles. These individual dominant follicle profiles were started when the follicle was first detected at a diameter of $0.5 \mathrm{~cm}$. The mean number of follicles present in both ovaries, from 20 days before to 20 days after a reference point, was tabulated in relation to the diameter of the largest follicle, to confirm that follicular growth occurred in waves. Because ovulation did not occur in group 1 and group 3 camels, this common reference point (day 0 ) was taken as the day on which the dominant follicle first reached its maximum diameter.

Experiment 2. The ovaries of all 60 camels included in the experiment were examined ultrasonographically on alternate days throughout the defined experimental periods. All follicles $\geq 0.5 \mathrm{~cm}$ in diameter were counted and measured and when the dominant follicle reached a diameter of $0.5-0.9 \mathrm{~cm}(n=30)$, $1.0-1.9 \mathrm{~cm}(n=51), 2.0-2.9 \mathrm{~cm}(n=48)$ or $>3 \mathrm{~cm}(n=45)$, the camel was assigned to one of three treatment groups to induce ovulation. These treatments were: (i) natural mating $(n=61)$; (ii) $20 \mu \mathrm{g}$ of the $\mathrm{GnRH}$ analogue, buserelin (Receptal: Hoechst Animal Health, Milton Keynes) given i.v. $(n=58)$; or (iii) 3000 iu hCG (Chorulon: Intervet Laboratories, Cambridge), also given i.v. $(n=55)$. The ovaries were rescanned at 36,48 , 72 and $96 \mathrm{~h}$ after treatment to monitor ovulation, which was confirmed subsequently by measuring a rise in peripheral serum progesterone concentrations. Some camels were used more than once in the experiment but, in each case, at least one complete follicular cycle was allowed to occur between successive treatments.

\section{Statistical analyses}

To investigate possible associations between the number of follicles and the diameter of the largest follicle, the product moment correlation coefficient $(r)$ was calculated. The result was confirmed by carrying out a periodic regression analysis using sine and cosine terms, as well as calculating the equivalent rank coefficient (Kendail's Tau). Student's $t$ test was used to compare cycles in which follicles grew to $1.5-2.5 \mathrm{~cm}$ in diameter with those in which they grew to $2.6-6.4 \mathrm{~cm}$ in diameter, and differences were considered to be significant if $P<0.05$. Fisher's exact test was used to compare the ovulation responses of follicles of different sizes. The relationship between oestradiol concentrations and follicle growth was emphasized by calculating the magnitude of the mean ( \pm SEM) differences between the time periods days $-8-0$, and days $0-+8$.

\section{Results}

\section{Experiment 1: follicular wave dynamics}

Although the follicular wave pattern varied considerably between individual camels in both group 1 and group 3, it was none the less clearly divisible into three phases in all animals: a growth phase, a mature phase and a regression phase (see Table 1; Fig. 3). New follicles became visible and started to grow before the mature follicle had fully regressed, to give a 
Table 1. Follicular growth patterns in cycles that resulted in dominant foilicles of $1.5-2.5 \mathrm{~cm}$ maximum diameter versus follicles of $2.6-6.4 \mathrm{~cm}$ diameter

\begin{tabular}{|c|c|c|c|}
\hline \multirow[b]{2}{*}{ Parameter } & \multicolumn{3}{|c|}{ Mean ( \pm SEM) duration (days) of } \\
\hline & Growth phase & Mature phase & Regression phase \\
\hline $\begin{array}{l}\text { Cycies that resulted in a dominant follicle with } \\
\text { a maximum diameter of } 1.5-2.5 \mathrm{~cm}(n=34)\end{array}$ & $10.5 \pm 0.5^{\mathrm{a}}$ & $7.6 \pm 0.8^{b}$ & $11.9 \pm 0.8^{c}$ \\
\hline $\begin{array}{l}\text { Cycles that resulted in an oversized follicle of } \\
2.6-6.4 \mathrm{~cm} \text { diameter }(n=32)\end{array}$ & $18.4 \pm 0.8^{\mathrm{a}}$ & $4.6 \pm 0.5^{b}$ & $15.3 \pm 1.1^{\mathrm{c}}$ \\
\hline
\end{tabular}

Means with the same superscript are significantly different: ${ }^{a} P<0.001 ;{ }^{b} P<0.01 ;{ }^{C} P<0.02$ (Student's $t$ test).

mean interwave interval of $18.2 \pm 1.0$ days. The dominant follicle reached a maximum diameter of $2.0 \pm 0.1 \mathrm{~cm}$ in $52 \%$ $(n=34)$ of the wave patterns studied before it began to regress (Fig. 4a). However, in the other 32 instances $(48 \%)$, the follicle continued to grow beyond $2.0 \mathrm{~cm}$ until it reached a mean ( \pm SEM) diameter of $4.1 \pm 0.2 \mathrm{~cm}$ (range $2.6-6.4 \mathrm{~cm}$; Fig. $4 \mathrm{~b}$ ). These oversized follicles took significantly longer to attain their maximum diameter $(P<0.001)$, and then to regress to $<0.5 \mathrm{~cm}(P<0.02)$, than did dominant follicles with maximum diameters of $1.5-2.5 \mathrm{~cm}$ (Table 1). During the regression process, the follicular fluid of the oversized follicles became increasingly echogenic owing to the development of freefloating echogenic strands, which later became organized into transecting fibrous bands (Fig. 4b). Nevertheless, these overlarge follicles did not inhibit the growth of other follicles in the same or contralateral ovary, which would mature and ovulate if the appropriate stimulus was applied (Fig. 4a).

There was a strong inverse relationship between the number of follicles in the ovaries and the diameter of the largest follicle. The product moment correlation coefficient for this relationship was calculated to be $r=-0.0627(P<0.003)$ and Kendall's coefficient of rank correlation confirmed the conclusion $(\tau=-0.467, P<0.004)$. The very pronounced cyclical pattern was investigated further by carrying out a periodic regression analysis, using sine and cosine terms. A highly significant correlation was detected for both variables $(r=0.823$ for follicle number and $r=0.883$ for follicle diameter). The data therefore provided strong confirmation of the cyclical variation in number of follicles and diameter of the largest follicle.

In group 2, the vasectomized male mated with the female camels when the mean ( \pm SEM) diameter of their dominant follicle was $1.3 \pm 0.1 \mathrm{~cm}$. Mating therefore significantly shortened the interwave interval from $18.2 \pm 1.0$ (group $I$ and group 3 camels) to $13.8 \pm 1.0$ days $(P<0.01)$. Ovulation in the mated camels was followed in $3-4$ days by the development of a spherical, echogenic corpus luteum that grew from a diameter of $0.7 \pm 0.2 \mathrm{~cm}$ on day 3 to $2.2 \pm 0.1 \mathrm{~cm}$ by day 9 (Fig. 4c). It exhibited a secretory lifespan of $8.5 \pm 0.5$ days, as reflected by the serum progesterone profile. Concentrations remained low $\left(<0.5 \mathrm{ng} \mathrm{ml}^{-1}\right)$ for the first 3-4 days after ovulation and then rose to reach a mean peak of $2.6 \mathrm{ng} \mathrm{ml}^{-1}$ on day 8 . They decreased again sharply on days 9 and 10 to reach baseline values of $<0.5 \mathrm{ng} \mathrm{ml}^{-1}$ by days 10-12. Progesterone concentrations in the non-mated camels in group 1 and group 3 remained low $\left(0.1-0.4 \mathrm{ng} \mathrm{ml}^{-1}\right)$ throughout the experimental period. New follicles became visible $5.1 \pm 0.5$ days after a first mating and they took $8.3 \pm 1.0$ days to mature to a diameter of $1.3 \pm 0.1 \mathrm{~cm}$ when the camel was remated by the vasectomized male.

An increase in both mean serum oestradiol concentrations $\left(+14.2 \pm 1.5 \mathrm{pg} \mathrm{ml}^{-1} ; P<0.001\right)$ and follicle growth $(+0.76 \pm 0.12 \mathrm{~cm}, P<0.001)$ occurred between days -8 and day 0 as the follicle grew to a diameter of $1.7 \pm 0.1 \mathrm{~cm}$ (Fig. 5). Between day 0 and day 8 , however, oestradiol concentrations decreased $\left(-11.9 \pm 1.6 \mathrm{pg} \mathrm{ml}^{-1} ; P<0.001\right)$, while follicle growth continued to increase $(+0.69 \pm 0.18 \mathrm{~cm}, P<0.01)$. Signs of oestrus in group 1 and group 2 females were highly variable and seemed to bear little relationship to follicle maturity. Individual camels would often show apparent oestrus when approached by the male, including stradling the hind legs, raising the tail and urinating, when there was little follicular activity in their ovaries. Only twice was a female observed to submit instantly to the male which, more often, would select a female that was definitely not showing visible oestrus. He would chase her around the pen biting her hump or hind legs until she submitted and allowed him to mate. Copulation in these group 2 camels lasted from 5 to $15 \mathrm{~min}$.

\section{Experiment 2: induction of ovulation}

Ultrasound scanning of the ovaries, combined with daily peripheral serum progesterone measurements, showed that of the 30 camels with a follicle of $0.5-0.9 \mathrm{~cm}$ in diameter, 7 of 10 $(70 \%)$ ovulated in response to mating, 6 of $10(60 \%)$ ovulated in response to buserelin and 6 of $10(60 \%)$ in response to hCG. However, reappraisal of the data revealed that of the 19 group I camels that ovulated, $16(85 \%)$ had a follicle of $0.9 \mathrm{~cm}$ in diameter and only three (15\%) had follicles between 0.5 and $0.8 \mathrm{~cm}$. Thus, it would appear that $0.9 \mathrm{~cm}$ is about the minimum ovulatory diameter of the Graffian follicle in dromedaries.

The ovulation rates rose, although not significantly, to $85 \%$ (17 of 20 ), $81 \%$ (13 of 16 ) and $67 \%$ (10 of 15), respectively, in the animals that were either mated or treated with GnRH or hCG when they had a $1.0-1.9 \mathrm{~cm}$ diameter follicle in their ovaries. The ovulation rates then decreased again sharply $(P<0.001)$ when the diameter of the follicle had increased to $2.0-2.9 \mathrm{~cm}$ at the time of treatment ( 2 of $16,12.5 \%$ for mating; 5 of $17,29 \%$ for buserelin and 2 of $15,13 \%$ for hCG), and Downloaded from Bioscientifica.com at 04/26/2023 01:16:54PM 



Fig. 3. Typical follicular wave profiles recorded in 6 unmated camels that did not develop overlarge follicles.

when the follicle had grown to $>3 \mathrm{~cm}$, none of the camels mated or treated with gonadotrophic hormones ovulated $(P<0.01)$.

Progesterone profiles during the luteal phase in the treated camels that ovulated were unaffected by the method used to induce ovulation. The mean peak concentrations of $2.5-3.0 \mathrm{ng}$ $\mathrm{ml}^{-1}$ in the mated and GnRH-treated groups were not significantly different from the mean peak value of $4.5 \mathrm{ng} \mathrm{ml}^{-1}$ in the hCG-treated camels $(P>0.1)$. Serum progesterone concentrations remained low $\left(<1.0 \mathrm{ng} \mathrm{ml}^{-1}\right)$ in all the camels that failed to ovulate in all three groups.

\section{Discussion}

The occurrence of waves of follicular activity in camels was indicated in the present study by periodic increases in the number of follicles present in the ovaries, from which one would grow to a mean maximum diameter of $2.0 \pm 0.1 \mathrm{~cm}$ or $4.1 \pm 0.2 \mathrm{~cm}$ while the others regressed. Furthermore, there was an inverse relationship between the diameter of the largest follicle and the number of follicles present, which is consistent with the follicular wave theory proposed for cows by Ginther et al. (1989) and for llamas by Adams et al. (1990). The diameter 

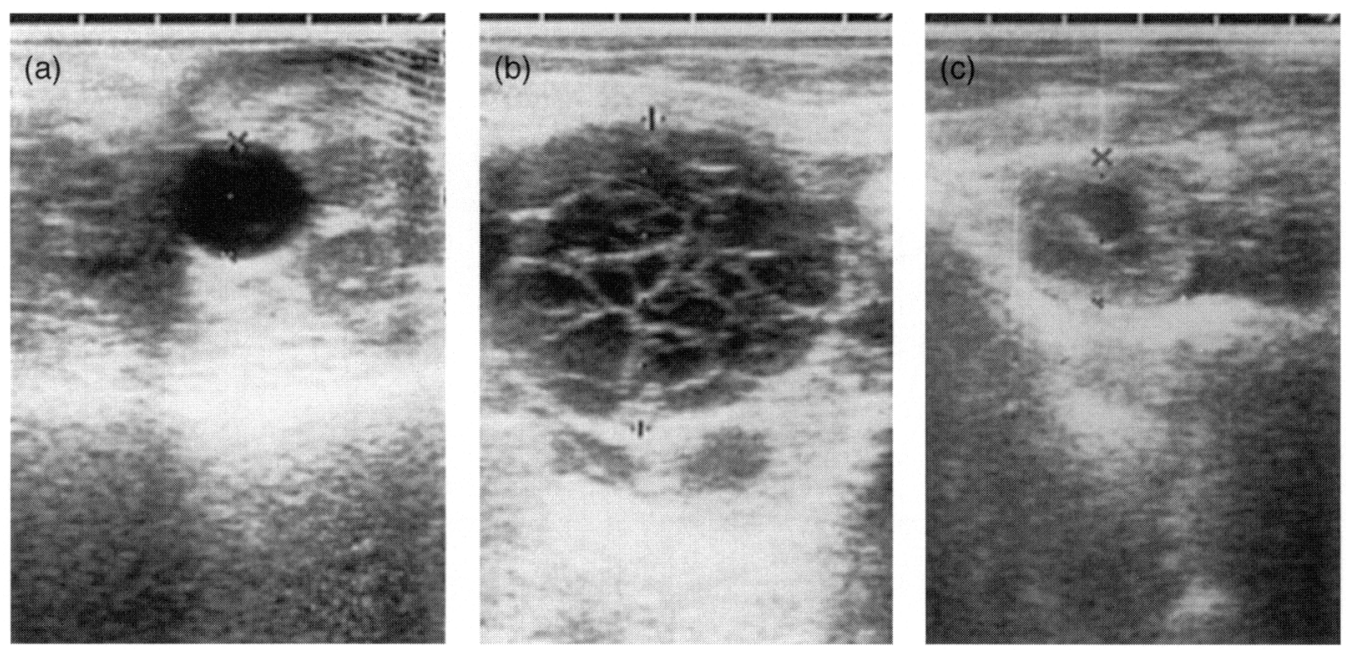

Fig. 4. Ultrasonographic appearance of (a) a normal mature preovulatory follicle of $1.7 \mathrm{~cm}$ diameter in the left ovary; (b) a large, overripe, unovulated regressing follicle of $4.8 \mathrm{~cm}$ diameter in the right ovary of the same camel, showing the characteristic echogenic transecting fibrinous strands in the follicular fluid; and (c) a typical echogenic corpus luteum with a persisting nonechogenic core on day 6 after ovulation.

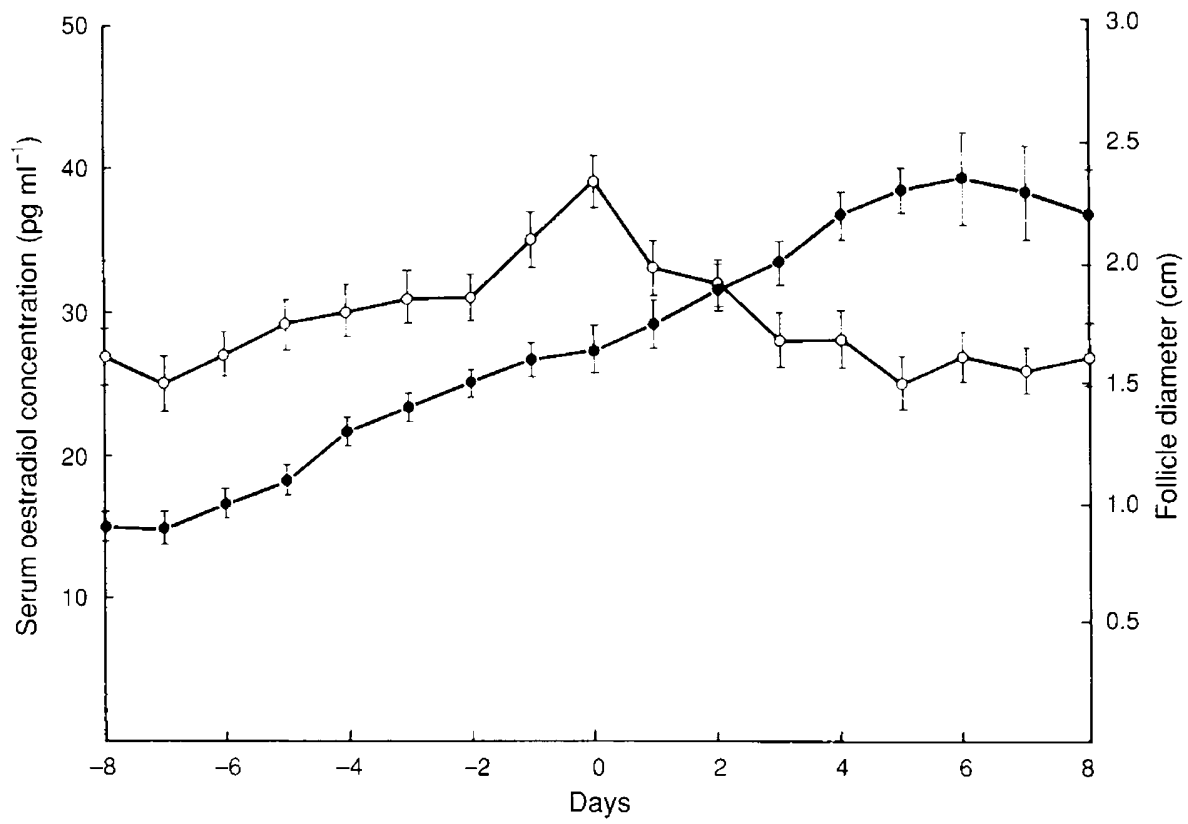

Fig. 5. Relationship between mean ( \pm SEM) serum oestradiol concentrations ( ) and mean ( \pm SEM) diameter of the dominant follicle ( ) in 8 unmated camels. Day 0 was taken as the day of maximum oestradiol concentration.

of the dominant follicle in the mated camels in group 2 $(1.3 \pm 0.1 \mathrm{~cm})$ was less than that of the dominant follicle in the non-mated camels in the other two groups, indicating that a follicle matures sufficiently to ovulate before it has reached maximum size. No overlarge follicle of $>3 \mathrm{~cm}$ diameter developed in any group 2 camels, presumably because they were mated when the dominant follicle reached maturity and this stimulated ovulation.

Similar oversized follicles that do not ovulate have been reported in llamas, and these all were the dominant follicle of a wave during which no copulatory stimulus had been applied (Adams et al., 1991a). The development of follicles larger than
$1.2 \mathrm{~cm}$ in diameter has been reported in alpacas by Sumar (1985) and Bravo and Sumar (1989), but these were considered to be pathological cysts on the basis of size alone. Clearly, these oversized follicles in both Old and New World camelids derive from the modern management practice of keeping male and female camels apart during the breeding season. However, the hormonal mechanisms that drive the development of such structures, and the reasons why they occur in only a proportion of unmated camels, have yet to be elucidated.

Follicular growth produced a peak of oestradiol in the serum but concentrations began to decline when the follicle grew to a diameter of more than $1.7 \mathrm{~cm}$. This suggests that the follicle Downloaded from Bioscientifica.com at 04/26/2023 01:16:54PM 
was already beginning to undergo atretic changes, perhaps as a result of a commencing downregulation of $\mathrm{LH}$ receptors in the theca interna or granulosa cell layers. Alternatively, it could be argued that a continuing basal secretion of $\mathrm{LH}$ from the pituitary gland, but in the absence of a true ovulatory $\mathrm{LH}$ surge, may be the cause of the overgrowth of some follicles beyond a diameter of $2.0 \mathrm{~cm}$.

The results of these experiments confirmed earlier observations of Marie and Anouassi (1987), Sheldrick et al. (1992) and Anouassi et al. (1992) that ovulation can be induced in dromedaries by a single treatment with GnRH or hCG. However, a significant finding of the present study was the marked reduction in the effectiveness of these hormone treatments and mating to induce ovulation when the diameter of the dominant follicle exceeded $2.0 \mathrm{~cm}$.

Peripheral serum progesterone profiles in the non-mated camels in groups 1 and 3 of Expt 1 showed that no spontaneous ovulations occurred, even in those animals that were close to, but not mated by, male camels. Profiles in the mated camels in group 2, and in the camels in Expt 2 that ovulated in response to treatment, showed that luteolysis commenced between day 8 and day 9 after ovulation and was complete by day 11. These findings agree with previous reports for dromedaries by Marie and Anouassi (1987) and bactrian camels by $\mathrm{Xu}$ et al. (1985), as well as those for New World camelids such as llamas (Adam et al., 1989; Adams et al., 1991b) and alpacas (Fernandez-Baca et al., 1970). It appears that the luteal phase of camelids differs from that of other induced ovulators like cats and ferrets, which become pseudopregnant. Camelids, therefore, have a reproductive advantage over these smaller, induced ovulating species, in that their much shorter luteal phase enables a more rapid return to a potentially fertile state.

In this study it was impossible to relate oestrous behaviour shown by the female camels to follicular activity in their ovaries and steroid hormone concentrations in their blood. More often than not, animals in groups 1 and 2 were either mated (group 2), or the male made a determined effort to mate them (group 1), when they appeared to resent his attention. Conversely, females showing clear signs of oestrus were ignored by the male. Oestrous behaviour has been reported to be equally variable in other camelids. For example, England et al. (1971) found it impossible to discern any major differences in behaviour patterns between animals with corpora lutea in their ovaries and those without.

In summary, a follicular wave pattern was found in dromedaries to consist of well defined, but individually variable, periods of growth, maturity and regression. The size of the dominant growing follicle and the display of oestrous signs by the female seem to bear little relationship to the desire of the male to mate the female concerned. Nevertheless, ovulation can be induced by GnRH or hCG, as well as natural mating, and an optimum time to treat the animal is when the growing follicle is between 0.9 and $1.9 \mathrm{~cm}$ diameter.

The authors thank A. Ridha and W. Tawfig of the New Dubai Hospital for assistance with the progesterone assays. They are also grateful to G. P. Adams of the Western College of Veterinary Medicine, Saskatoon, Canada and D. E. Walters of Cambridge, UK, for help with statistical analyses. The study was kindly sponsored by $\mathrm{H}$. $\mathrm{H}$. Sheikh Mohammed bin Rashid al Maktoum, Crown Prince of Dubai.

\section{References}

Adam CL, Moir CE and Shiach P (1989) Plasma progesterone concentrations in pregnant and non-pregnant llamas (Llama glama) Veterinary Record 125 $618-620$

Adams GP, Sumar J and Ginther OJ (1990) Effects of lactational and reproductive status on ovarian follicular waves in llamas (Llama glama) Journal of Reproduction and Fertility 90 535-545

Adams GP, Sumar J and Ginther OJ (1991a) Hemorrhagic ovarian follicles in Ilamas Theriogenology 35 557-565

Adams GP, Sumar J and Ginther OJ (1991b) The form and function of the corpus luteum in llamas Animal Reproduction Science 24 127-138

Anouassi A, Adnani M and El Raed M (1992) Artificial insemination in the camel requires induction of ovulation to achieve pregnancy. In Proceedings of the First International Camel Conference pp 175-178 Eds WR Allen, AJ Higgins, IG Mayhew, DH Snow and JF Wade. R\&W Publications, Newmarket

Bravo PW and Sumar J (1989) Laproscopic examination of the ovarian activity in Alpacas Animal Reproduction Science 21 271-281

Bravo PW, Fowler ME, Stabenfeldt GH and Lasley BL (1990) Ovarian follicular dynamics in the llama Biology of Reproduction 43 579-585

Chen BX and Yuen ZX (1979) Reproductive pattern of the Bactrian camel. In The Camel: an All Purpose Animal Vol. I pp 364-396 Ed. WR Cockrill. Scandinavian Institute of African Studies, Uppsala

Chen BX, Yuen ZX and Pan GW (1985) Semen-induced ovulation in the Bactrian camel Journal of Reproduction and Fertility 4 335-339

Cooper MJ, Skidmore JA, Allen WR, Wensvoort S, Billah M, Ali Chaudhry M and Billah AM (1992) Attempts to stimulate and synchronise ovulation and superovulation in dromedary camels for embryo transfer. In Proceedings of the First International Camel Conference pp 187-191 Eds WR Allen, AJ Higgins, IG Mayhew, DH Snow and JF Wade. R\&W Publications, Newmarket

Dighe KK and Hunter WR (1976) A solid phase radioimmunoassay for plasma progesterone Biochemical Journal 143 219-223

England BG, Foote WC, Cardozo AG, Matthews DH and Riera S (1971) Oestrous and mating behaviour in the llama (Llama glama) Animal Behaviour 19 $722-726$

Fernandez-Baca S, Madden DHL and Novoa C (1970) Effect of different mating stimuli on induction of ovulation in the alpaca Journal of Reproduction and Fertility 22 261-267

Fortune JE, Sirois J and Quirk SM (1988) The growth and differentiation of ovarian follicles during the bovine estrous cycle Theriogenology 29 95-110

Ginther OJ, Knopf L and Kastelic JP (1989) Temporal associations among ovarian events in cattle during oestrous cycles with two and three follicular waves Journal of Reproduction and Fertility $87223-230$

Heap RB and Hamon M (1979) Oestrone sulphate in milk as an indicator of a viable conceptus in cows British Veterinary Journal 135 355-363

Joshi CK, Vyas KK and Pareek PK (1978) Studies on the oestrous cycle in Bikaneri she-camels Indian Journal of Animal Science 48 141-145

Marie M and Anouassi A (1987) Induction of luteal activity and progesterone secretion in the non-pregnant one-humped camel (Camelus dromedarius) Journal of Reproduction and Fertility 80 183-192

Musa B and Abusineina ME (1978) The oestrous cycle of the camel (Camelus dromedarius) Veterinary Record 103 556-557

Pierson RA and Ginther OJ (1987) Follicular population dynamics during the estrous cycle of the mare Animal Reproduction Science 14 219-231

Pierson RA and Ginther OJ (1988) Ultrasonic imaging of the ovaries and uterus in cattle Theriogenology 29 21-37

Ravindra JP, Rawlings NC, Evans ACO and Adams GP (1994) Ultrasonographic study of ovarian follicular dynamics in ewes during the oestrous cycle Journal of Reproduction and Fertility 101 501-509

Savio JD, Keenan L, Boland MP and Roche JF (1988) Pattern of growth of dominant follicles during the oestrous cycle in heifers Journal of Reproduction and Fertility 83 663-671

Sheldrick LE, Flick-Smith H, Skidmore JA, Wensvoort S, Billah M, Ali Chaudhry M and Allen WR (1992) LH release profiles in female dromedary camels following mechanical and hormonal stimuli to induce ovulation. In Proceedings of the First International Camel Conference $\mathrm{p} 407$ Eds WR Allen, AJ Higgins, IG Mayhew, DH Snow and JF Wade. R\&W Publications, Newmarket

Skidmore JA, Billah M and Allen WR (1992) Ultrasonographic and videoendoscopic monitoring of early fetal development in the dromedary camel. Downloaded from Bioscientifica.com at 04/26/2023 01:16:54PM 
In Proceedings of the First International Camel Conference pp 193-201 Eds WR Allen, AJ Higgins, IG Mayhew, DH Snow and JF Wade. R\&W Publications, Newmarket

Sirois $\mathrm{J}$ and Fortune JE (1988) Ovarian follicular dynamics during the estrous cycle in heifers monitored by real-time ultrasonography Biology of Reproduction 39 308-317

Sirois J, Ball BA and Fortune JE (1989) Patterns of growth and regression of ovarian follicles during the oestrous cycle and after hemiovariectomy in mares Equine Veterinary Journal Supplement 8 43-48

Sumar J (1985) Reproductive physiology in South American camelids. In Genetics of Reproduction in Sheep pp 81-95 Eds RB Land and DW Robinson. Butterworths, London
Whitehead TP, Thorpe EHG, Carter JJN, Groucutt C and Kricka LJ (1983) Enhanced luminescence procedure for sensitive determination of peroxidaselabelled conjugates in immunoassay Nature 305 158-159

Wilson RT (1984) The Camel pp 53-102. Longmans, London

Xu YS, Jian LG, Wang HY, Ge SL, Zeng GQ, Jiang GT and Gao YH (1985) Hormone concentrations before and after induced ovulation in the Bactrian camel (Cameius bactrianus) Journal of Reproduction and Fertility $\mathbf{7 4}$ 341-346

Zhao XX, Pan GW, Huang YM and Chen BX (1990) Studies on the ovulation inducing factor in the seminal plasma of the Bactrian camel. In Proceedings of the Workshop 'Is it Possible to Improve the Reproductive Performance of the Camel?" pp 197-210 Ed. G Saint-Martin. CIRAO-EMVT, Paris 